\title{
DE PROBLEMATIEK VAN TRANSSEXUALITEIT EN OPERATIEVE VERANDERINGEN AAN HET MENSELIJK LICHAAM VANUIT WIJSGERIG- ANTROPOLOGISCH EN ETHISCH PERSPECTIEF.
}

\author{
M. Valenkamp \\ Faculteit Wijsbegeerte \\ Vrije Universiteit \\ AMSTERDAM
}

\begin{abstract}
The purpose of this contribution is to discuss the question of detranssexualization of gender-dysfore persons. On grounds of scientific research into the nature and nurture aspects of personality development and the lack of bio-chemical grounds for a transsexual personality development, I will defend that it is a coinmand of love to accept the plea for chinurchical treatment of gender-dysfore persons.
\end{abstract}

\section{INLEIDING}

De wijze waarop de ethiek zich met de verschillende werkelijkheidsaspekten bezig mag houden, is het onderzoeken van de structuur van de in die werkelijkheidssferen aanwezige morele normativiteit. In deze bijdrage zal het gaan om het aangeven van de mogelijkheden van de ethiek van reformatorisch wijsgerige huize om te komen tot een afgewogen standpunt inzake de toelaatbaarheid van endocriene en transformatieve chirurgische ${ }^{1}$ ingrepen ten aanzien van de transsexuele mens. Antropologische uit-

\footnotetext{
1 Ten Have en Kingsma(1987:166-167) maken de opmerking dat tengevolge van de technische ontwikkelingen de klassieke indeling van het medisch handelen in curatieve en preventieve activiteiten niet langer houdbaar is. Een derde term is nodig, namelijk die van transformerende geneeskunde. Ze geven de volgende omschrijving van deze nieuwe term: Transformerende genceskunde is geneeskunde die de normale vorm en functic van het lichaam alsook het normale gedrag van mensen verandert. Hierbij is dus in strikte zin geen sprake van curatie of preventic. Er is geen curatic, omdat er geen sprake behoeft te zijn van ziekten of afwijkingen. $\mathrm{Er}_{\mathrm{r}}$ is evenmin preventic omdat er geen potentiële schade kan worden aangegeven." Schrijvers waarderen deze ontwikkeling zeer kritisch, namelijk als een blijk van 'een volgende stap in het kader van bcheersing van het menselijk leven'.
} 
gangspunten, zoals die in de analyse van het liefdes-'begrip' door zullen klinken, zullen mijn bijdrage sturen, want, is het niet waar wat Fromm (1971:18) schreef, dat "iedere beschouwing over liefde moet uitgaan van een mensbeschouwing, van een overdenking van het menselijk bestaan". Verder sluit ik met mijn aandacht geven aan de antropologische vragen in het kader van het probleem van de transsexualiteit, aan bij de gedachte, dat een praxeologische bestudering van de totaliteit van het menselijk handelen als uitgangspunt de antropologie veronderstelt.

1.1 De morele dilemma's ten aansien van de detranssexualisatie ${ }^{2}$ via endocrinologische en transformatief chirurgisch handelen

De morele vraag waarvoor een arts/chirurg zich gesteld ziet als de transsexuele mens zich tot hem om hulp wendt is: "Moet de geneeskunde de transsexueel volgen in het primaat van de eigen overtuiging, dwars tegen de biologische werkelijkheid in? (... ) Verstoort de transsexueel met zijn wensen niet een fundamentele ordening van de natuur?" (Gooren, 1987:20). Moeten we het door God gegeven lichaam niet in zijn ongeschondenheid laten bestaan, ook al lijkt de transsexuele mens dit lichaam als een kerker te ervaren?

\subsection{De benadering van het onderhavige probleem}

Sporken (1979) geeft aan, dat de ethische reflectie in drie fasen verloopt: de fase van de beschrijving en de analyse van de menselijke probleemsituaties en van de normen, die op het betreffende levensgebied reeds voorhanden zijn of als nieuwe normen worden voorgesteld. De tweede fase bestaat uit de verheldering van het mensbeeld dat in de normen tot uitdrukking komt en de derde "en moeilijkste fase van de ethische reflectie bestaat in een kritische toetsing van het ontdekte mensbeeld op de authenticiteit en het humaniteitskarakter ervan" (Sporken, 1977:26-27). In zekere mate Sporken volgende wil ik eerst een descriptie van het fenomeen transsexualiteit geven in die beschrijving wil ik een aantal misvattingen over transsexualiteit wegnemen. Als

\footnotetext{
2 Men moet er op bedacht zijn, dat er tegen de term detranssexualisatie bezwaar kan worden gemaakt, omdat deze term de transsexueel een illusie biedt. Gooren (1987:13; 1990:12) schrijft: "De huidige endocriene en chirurgische mogelijkheden zijn van dien aard dat ze slechts een deeloplossing bieden voor het probleem van de gender-dysfore patiënt. (...) De term detranssexualiteit is dárom misleidend omdat deze zou suggereren dat de transsexueel na de hormonale en chirurgische therapie genezen en van zijn problemen af zou zijn, en dat is een simplisme. Het blijft een gebrekkige aanpassing aan het als eigen ervaren geslacht van de transsexueel."
} 
tweede wil ik me afvragen of antropologische schema's wel passen op het genderdysfore ${ }^{3}$ persoonlijkheidsbeeld van de transsexuele mens en ten slotte wil ik komen tot een afgewogen standpunt inzake de toelaatbaarheid van endocrinologische en geslachtsaanpassende chirurgische ingrepen ten aanzien van de transsexuele mens.

\subsection{Het verschijnsel transsexualiteit.}

Het verschijnsel transsexualiteit is te omschrijven als "een incongruentie, een tegenstelling tussen enerzijds de lichamelijk waarneembare en objectiveerbare geslachtelijke differentiatie en anderzijds de zelfbeleving man of vrouw te zijn". Het wezenlijke kenmerk van de transsexualiteit is, "dat zich naar onze huidige maatstaven en inzichten, een volkomen normale lichamelijke geslachtelijke differentiatie heeft voltrokken in een individu en dat het zelfde individu met grote hardnekkigheid beweert een lid te zijn van het andere geslacht en een gedrevenheid aan de dag legt om het lichaam aan te passen aan het andere geslacht" (Gooren, 1987:194-196 en 275-276).

In de diagnosestelling (het DSM-III ${ }^{4}$ ) worden de volgende criteria voor het vaststellen van het transsexueel-zijn gegeven:

* Een gevoel van onbehagen en disharmonie met het eigen anatomische geslacht.

* De wens om van de eigen genitaliën verlost te worden en te leven als lid van het andere geslacht.

* De gevoelens genoemd onder de eerste twee criteria zijn continu aanwezig geweest gedurende tenminste twee jaar.

* Er is geen sprake van lichamelijke intersexe of genetische abnormaliteit.

* Er is geen sprake van mentale stoornissen, zoals schizofrenie, psychosen, enzovoort.

\footnotetext{
${ }^{3}$ Gender = geslacht, genus. Het woord gender slaat niet louter op de biologische kant van de menselijke geslachtelijkheid, maar ook op iemands psychische, sociale en juridische geslachtelijkheid.

${ }^{4}$ De letters DSM zijn een afkorting van Diagnostic and statistical manual of mental disorders - III, zoals door de Amerikaanse Psychiatrische Associatie is uitgegeven. Washington, D.C. 1980
} 
Het verschijnsel transsexualiteit is verder geen eenduidig fenomeen. In 1966 stelde $\mathbf{H}$. Benjamin een Sex orientation scale op en kwam tot een indeling in drie categorieën:

* De niet operatief transsexuelen. Deze transsexuelen hebben een wisselend identiteitsgevoel, leven vaak afwisselend als man en vrouw en streven niet altijd een operatieve geslachtsaanpassing na, maar onderwerpen zich soms wel aan een hormoonbehandeling.

* De echte transsexuelen, vèrgaand. Deze mensen leven en voelen zich duidelijk een lid van het fysiek andere geslacht. Sexueel zijn de mannelijke vergaande transsexuelen soms op mannen, soms op vrouwen gericht. Deze vergaande transsexuelen streven meestal een operatieve en hormonale behandeling na.

* De echte transsexuelen, zeer vèrgaand. Deze transsexuelen, als het fysiek mannen zijn, leven zoveel mogelijk als vrouw, hebben een intense afkeer van hun eigen lichaam en streven naar volkomen geslachtsaanpassing. De mannelijke transsexuelen, zeer vèrgaand, zijn gericht op heterosexuele mannen 5 .

Is de boven gegeven indeling van transsexualiteit een graduele, namelijk de mate waarin men geslachtsveranderende handelingen van de medische deskundigheid verwacht, op grond van de mate warin men zich ontevreden voelt met de fysieke en geestelijke incongruentie, de hieronder te geven indeling is gebaseerd op de leeftijdsfasen waarin mensen bij zichzelf het besef ontdekten 'anders' te zijn.

Op grond van een biografisch onderzoek, zoals deze in 1980 is gedaan en in 1984 is herhaald, stelde Verschoor en Poortinga (1986) de volgende indeling op:

\footnotetext{
5 Zie het schema van de Sex orientation scale van Benjamin op bladzij 387 van dit artikel (Bron: Benjamin, 1966. Overgenomen uit Gooren, 1986:20).
} 
De sex orientatie schaal van Benjamin

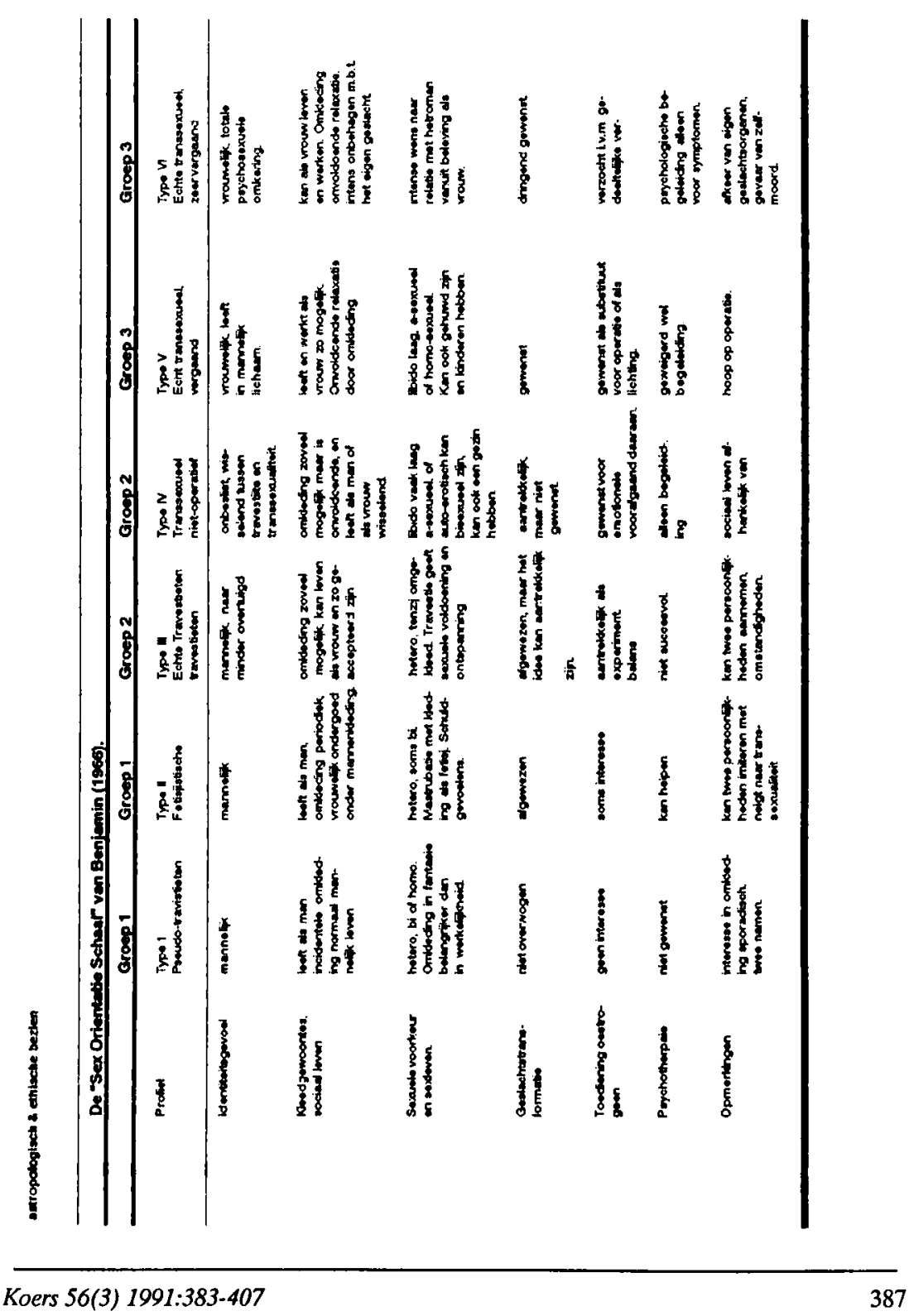


Die problematiek van transsexualiteit

Tabel 1: Het eerste besef 'anders'6 te zijn in procenten per categorie.

$\begin{array}{lllll} & \text { MV } & \text { VM } & \text { TR } & \text { Onzeker } \\ \text { Vo6r het 6de jaar } & 51,5 & 63,5 & 22,6 & 28,6 \\ \text { 6 tot 12 jaar } & 41,2 & 32,4 & 40,7 & 42,9 \\ 12 \text { jaar en ouder } & 7,3 & 4,1 & 36,7 & 28,6\end{array}$

Met deze indeling volgens leeftijdscategorie van het besef anders te zijn, hebben we namelijk een indeling die tot de pragmatische hantering van de begrippen primaire en secundaire transsexualiteit voerde (Person \& Oversey, 1974:4-20). Bij de primaire transsexualiteit gaat het om mensen, die een volledig transsexuele ontwikkeling doormaken en dat al van vór het zesde levensjaar. Bij secundaire transsexualiteit gaat het dan om homosexuelen of travestieten, die in een perioden van stress transsexueel worden. De biografische indeling van Verschoor en Poortinga legt de nadruk op het altijd al gevoeld te hebben 'anders' te zijn. De primaire transsexueel heeft dat gevoel dan al van vóór het zesde levensjaar, terwijl de secundair transsexuelen de incongruentie tussen lichaam en zelfgevoel pas in of na de puberteit gingen beseffen. Verschoor wijst erop, dat de secundaire transsexuelen een symptomatologie vertonen, die duidelijk afwijkend is van wat men gebruikelijk in de anamnese tegenkomt ${ }^{7}$.

Met de onderscheidingen van Person en Oversey en die van Verschoor ontdekken we tevens het wezenlijkste kenmerk van de transsexualiteit, namelijk die van de identiteitsbeleving van de transsexueel.

Transsexualiteit is geen sexueel probleem, lijkt geen biologische weeffout (Gooren, 1986:50-56), maar is boven alles een identiteitsprobleem: het is een worstelen met de vraag tot welk geslacht men eigenlijk behoort? In navolging van Money en Erhardt (1972) is men in Nederland het begrip gender-identiteit gaan gebruiken. En met het begrip gender-identiteit bedoelt men dan ook het gevoel man of vrouw te zijn in de breedste zin van dat woord en met alle gender-rollen die daarbij behoren. Daar waar mensen een niet aflatende onvrede of onbehagen met zijn gender-identiteit en bijbeho-

\footnotetext{
${ }^{6}$ N.B. dat de term 'anders' hier betekent dat de cliënt voelde op een of andere manier niet te bchoren tot de groep leeftijdsgenoten van dezelfde biologische sexe, de aansluiting miste bij kinderspelletjes, enzovoort. Als verdere uitleg van dit schema de volgende opmerking: met $M V$ wordt bedoeld die transsexuelen, die van man naar vrouw willen veranderen. $V M$ slaat dan op vouwen die naar man willen veranderen. $T R$ is de afkorting van travestieten.

${ }^{7}$ De vraag hoe dit komt is nog moeilijk te beantwoorden. Verschoor (1986:48) stelt de volgende tentatieve vragen: Is de gender-dysforie minder sterk? Is het verzet ertegen groter? Is het ecn reactie op een mocilijke lcvensfase?
} 
rende gender-rollen ervaart, spreekt men van gender-dysforie. Personen, die nu in extreme mate (zeer vèrgaand) gender-dysfoor zijn en aanhoudend aangeven dat een geslachtstransformatie dringend gewenst is, worden dan echte transsexuelen genoemd ${ }^{8}$.

De ernst van de aanhoudende wens tot geslachtstransformatie moge blijken uit een studie van Eicher (1985). Eicher ontdekte dat onder de (nog) niet behandelde transsexuelen een relatief hoog percentage suïcidaliteit (ong. 15\%) en een extreem hoge mate van diverse soorten automutilatie ${ }^{9}$ voorkomt, terwijl er verder sprake is van jarenlange zielestrijd en grote psychische nood.

\subsubsection{Verklaringen voor het ontstaan van het verschijnsel transsexualiteit.}

Tot de descriptie van het verschijnsel transsexualiteit behoort ook een behandeling van haar ontstaanswijse, te meer omdat daar waar transsexualiteit of als een biologische of als een sociale 'vergroeiing' zou worden aangemerkt voor de ethicus, twee wegen begaanbaar zijn, namelijk: of stellen dat bij een biologische oorsprong van de genderdysforie endocriene en transformatieve hulp de enige uitweg lijkt, als zaken als aanvaarding en ascese geen begaanbare wegen blijken, of zeggen, dat eerst onderzocht moet worden wat in de sociale interactiepatronen tussen opvoedingsmilieu ${ }^{10}$ en kind oorzaak is van die 'vergroeiing', vervolgens om te zien of de gevolgen van de sociale beïnvloeding reversibel zouden zijn. De door mij verdedigde stellingname in dit artikel, is dat de ethicus een derde weg moet gaan, omdat er noch significante bewijzen voor een biologische wortel, noch significante argumenten voor een sociale oorsprong van de gender-dysforie voorhanden zijn. Die derde weg zal dan lopen via de vragen van zin of kwaliteit van mens-zijn, dus via de antropologische problematiek van het mens-zijn!

\footnotetext{
${ }^{8}$ In de Sex orietation scale van Benjamin vormen deze laatsten groep dric.

${ }^{9}$ Eicher noemt de volgende getallen van vormen van automutilatie: bet wegbinden van borsten bij (nog) niet behandelde VM-transsexuelen (40\%), het omhoogdrukken van de testes en/of wegdrukken van de penis $(60 \%)$, verminking van het scrotum $(6 \%)$ en een enkele zelfcastratie of penectomie bij MV-transsexuelen.

${ }^{10} \mathrm{Genomen}$ in de breedste zin van dat woord, namelijk en opvoedings- en omgangspatronen tussen ouders en kind, maar ook de hele culturele context, die - volgens sommigen - cen verschijnsel als transscxualiteit zou kunnen bevorderen.
} 


\subsubsection{Biologische wortels van het verschijnsel transsexualiteit?}

Nog in 1974 maakte Van Emde Boas (1974:475) in Medisch Contact een onderscheiding tussen de neurotische en de constitutionele transsexualiteit ${ }^{11} \mathrm{en}$ wel nagelang de gender-dysforie op enigerlei wijze verworven dan wel aangeboren is. De neurotische transsexualiteit zou dan met behulp van psychotherapie 'verholpen' kunnen worden, terwijl middels hormonale en plastische chirurgie de constitutionele transsexuele mens geholpen kan worden. De huidige kennis over de ethologie van de transsexualiteit maakt het niet aannemelijk dat er biologische factoren bij transsexuelen zijn aan te wijzen voor de verklaring van het fenomeen transsexualiteit. Gooren vermeldt een genetisch geslachtsonderzoek bij 321 transsexuelen waarbij slechts één ${ }^{12}$ cliënt afweek van het normale gonadale/genitale geslacht (mannen dus een genetische configuratie van 46XY en vrouwen een 46XX chromosomen). Verder vermeldt Gooren, dat er onder zijn patiënten zes transsexuelen voorkomen, die de helft van een tweeling zijn, waarbij de andere helft van de tweeling geen gender-indentiteitsproblemen heeft. Een (te) gering vermoeden van een biologisch substraat zou kunnen zijn, dat er een monozygotische tweeling en twee zusjes van deze tweeling zijn, die alle vier in behandeling zijn ter aanpassing aan de mannelijke geslachtsrol. Ook onderzoek naar de basale spiegels van testosteron, oestradiol, prolactine en gonadotrifine-response op LHRH, de LH-response op oestrogeentoediening bij deze 321 transsexuelen bracht geen significante afwijkingen aan het licht (Gooren, 1986:55).

\subsubsection{Postnatale wortels van het verschijnsel transsexualiteit?}

Als mogelijke postnatale oorzaken van transsexualiteit komen de volgende mogelijkheden in aanmerking (1) psychiatrisch te classificeren problemen, (2) opvoedingsinvloeden en (3) stimulerende culturele tendensen

\footnotetext{
${ }^{11}$ Verder verwijst Van Emde Boas ook naar een derde maar zelden voorkomende vorm van psychotische transseksisme, welke door Van Emde Boas Geschlechtsverwandlungswahn is genocmd. Ook hier lijkt psychotherapie gecontraïndiceerd.

${ }^{12}$ Dit betrof dan 'n cliënt met het syndroom van Klinefelter (46 XXY-chromosomen - Landman, 1969:80).
} 


\subsubsection{Psychiatrisch te classificeren wortels?}

Van Emde Boas maakte, zo zagen we, het onderscheid tussen twee vormen van transsexualiteit, één daarvan was de zogenaamd neurotische vorm. Transsexualiteit zou dan een neurose zijn. Een andere, oude benadering vanuit de psychiatrie was de mening dat de gender-dysfore mens op éen punt in zijn leven, namelijk het punt van de werkelijkheid van zijn geslachtelijke differentiatie, de kenmerken van een psychose vertoont, door gestoord te zijn in zijn cognitieve vermogens en zijn reality testing. In de terminologie van de psychiater met genoemde opvatting werd dan de - volgens Gooren niets zeggende - diagnose monosymptomatische psychose gesteld (Gooren, 1987:12), of ook wel schizofrene psychose. Weer anderen typeerden de transsexualiteit als een waan, een niet te corrigeren denkstoornis (Huyse, 1986:59).

De nieuwere inzichten in het fenomeen van de transsexualiteit, welke nu als basis dienen van de diagnostische criteria van de DSM-III en haar in dat Handboek een eigen plaats opleverde, leveren het volgende beeld op:

* Transsexualiteit is geen perversie.

- Transsexualiteit is geen vorm van homosexualiteit ${ }^{13}$.

* Transsexualiteit staat niet in verband met schizofrene psychosen.

- Transsexualiteit wordt (voorlopig ${ }^{14}$ ) ingedeeld bij de syndromale stoornissen ${ }^{15}$.

* In tegenstelling tot de homosexualiteit wordt de transsexualiteit altijd als pathologisch gezien.

\footnotetext{
${ }^{13}$ Op dit punt verwijs ik naar een ingezonden stuk in Nederlands Dagblad van dr. A.H. van den Bout, orthopedisch chirurg uit Pretoria. Deze Van den Bout reageert op een artikel over transsexualiteit van Douma (1988) en wijst er in die reactie op, dat de homofiel en die transsexueel "beiden dezelfde geaardheid hebben". Transsexualiteit zou een methode zijn om homosexualiteit te vermijden. Het DMS-III zowel als de Nederlandse Gender Stichting, steun vindende in die Sex orientation scale van Benjamin, menen nu dat zo een standpunt als van Van den Bout ondeugdelijk is.

${ }^{14}$ Huyse (1986:61) merkt op: "De geschiedenis zal moeten uitwijzen in hoeverre deze positie juist is, of dat er een verschuiving dient te komen in de richting van bet normale naar analogie met de homosexualiteit." In ieder geval hebben onderzoekingen van Huyse laten zien dat de transscxuele onderzoekpopulatic weinig syndromale (psychotische, depressieve of angst-) pathologie vertoonde.

${ }^{15}$ Dit wil zeggen: een stoornis waarbij de samenhang der symptomen nog niet recht duidelik is (Pinkhof, 1963).
} 
* Wat karakterologisch kan worden opgemerkt is, dat de transsexuele mens een van zeer ernstige tot geheel afwezige karakterpathologie kan vertonen. Maar overwegend is de afwezigheid van die pathologie en de sterke egosyntoniteit ${ }^{16}$ van het verschijnsel.

De conclusie, die zich uit bovenstaande opdringt, is dat er weinig tot geen als psychiatrisch te classificeren problemen aanleiding tot transsexualiteit lijken te zijn.

\subsubsection{Eventuele verkeerde opvoedingsinvloeden?}

Omdat het fenomeen transsexualiteit zich lijkt toe te spitsen op de vraag 'wie ben ik eigenlijk, man of vrouw?', dus op de vraag naar de identiteit en de daarbij behorende sexrollen zou het hier interessant zijn na te gaan in welke mate zaken als opvoeding, hechting, sex-typing, narcistische projectie, anaclytische identificatie en ouderlijke overdracht (in Freudiaanse zin te verstaan), enzovoort de gronden kunnen zijn voor het ontstaan van de gender-dysforie bij hun kinderen. In het kader van deze bijdrage zou zo een onderzoek te ver voeren. Maar duidelijk is, dat het de ouders zijn, die in hun omgang met hun kinderen de basis leggen voor de persoonlijkheidsontwikkeling van hun kind. Ook, dat een verkeerde uitwerking van die opvoedingsfouten de basis vormen van een scheefgroei van onomkeerbare aard van de persoonlijkheidsontwikkeling. Zo wezen bijvoorbeeld Bowlby (1971), Lamb (1974:376-385), Van IJzendoorn, et al. (1988) op de grote rol van de moederliefde in het leven van het kind. Het ontbreken van een goede gehechtheidsrelatie zou onomkeerbare gevolgen hebben voor de mental health of de adaptability van het kind. Kern van Bowlby's attachment theorie was de boodschap, dat het ontbreken van een duurzame gehechtheidsrelatie in de eerste levensjaren voert tot problemen in de persoonlijkheidsontwikkeling. Greene (1955), Richter (1963), Miller (1981) en anderen benadrukken de wijzen waarop ouders hun kinderen niet de ruimte laten een eigen ik-ontwikkeling door te maken, maar hun kinderen narcistisch te bezetten, hen tot object van hun wensen, frustraties, verlangens, zinvervulling van hun bestaan 17 en herhalingsdwang te maken ${ }^{18}$.

\footnotetext{
${ }^{16}$ Dit wil zeggen: het niet ik-vrecmd zijn van gevoclens, of: het gevoel van bij mij te behoren.

${ }^{17}$ Green (1946 en 1955) sprak van moeders die hun kinderen zo heet inbakeren in hun affectieve ambivalentie, welke geworteld is en een te sterk verlangen een zinvol bestaan als moeder en huisvrouw te vinden, dat zij als het ware de persoonlijkheid van hun kinderen opslurpen en het opvoeden tot wat zij belangrijk achten, waardoor het kind geen psychische ruimte gegeven wordt zelf iemand te zijn. Green noemde dit verschijnsel "personality absorption".
}

${ }^{18}$ In deze verwijs ik naar wat S. Freud (1967:113-114) en in diens voetspoor neo-Freudianen als Anna Freud (1965), Richter (1963), Erikson (1967:205), Miller (1981 en 1981), en anderen 
Binnen de leerpsychologische beschouwingen over sex-typing hebben onder anderen Bandura, Ross en Ross (1969) de nadruk gelegd op de wijze waarop ouders hun kinderen leren wat de specifieke mannelijke en vrouwelijke rolgedragingen, opvattingen, attituden en activiteiten zijn. Het zou voor hen, die van mening zijn dat de genderdysforie een verworvenheid van de opvoedingsinvloed is, aantrekkelijk zijn te onderzoeken of kinderen met ouders die of gender-diffuus zijn, of één overduidelijk dominante ouder met sterk masculien of feminien gedrag een significant grotere kans op gender-dysforie hebben.

Kortom: uitgaande van de zo juist genoemde theorieën zou de vraag gesteld kunnen worden of er in de jonge kinderjaren van de transsexuelen van duidelijk afwijkende gezins- en ouder-kindrelaties sprake was. Dat laatste blijkt niet het geval. CohenKettenis verwijst naar onderzoeken waarin met name gezocht werd naar de relatie tussen aanwijsbare afwijkende gezinssituaties en het voorkomen van transsexualiteit bij kinderen uit deze gezinnen. Als samenvatting van de onderzoekingen van Stoller (1972), Tsoi (1977), Eicher (1985) en Verschoor (1986) maakt Cohen-Kettenis volgende opmerkingen. In de onderzoeksgroepen kwamen verschillende percentages scheidingen van een van beide ouders vóor het vijfde levensjaar (bijvoorbeeld door ziekte, sterfgevallen of uit huisplaatsing), afwezigheid van een der ouders, agressiviteit van de vader, dominantie van de moeder of een slecht huwelijk van de ouders voor. Maar in schijnbaar stabiele gezinsverhoudingen treft men eveneens transsexualiteit aan, terwijl kinderen uit even ongunstige gezinssituaties geen gender-dysforie ontwikkelen. Cohen-Kettenis concludeert: "... als er opvoedingsfactoren een rol spelen, dan zijn zij waarschijnlijk subtiel en talrijk en in complexe interactie met elkaar" (Cohen-Kettenis, 1986:23-24).

Zijn er dan geen directe aanwijzingen voor verkeerde pedagogische en relationele oorzaken van transsexualiteit aan te wijzen, op een indirecte wijze blijkt het consistente gedrag van ouders om hun zonen en dochters gelijk vanaf de geboorte als jongens en

opmerken over de zogenaamde herhalingsdwang bij volwassenen. Freud, c.s. leggen de dwang van de volwassene tot herhaling van wat het als kind (reeds in diens zeer jonge jaren) zag, meemaakte of moest ondergaan uit als "variaties op een thema dat hij niet heeft leren overwinnen en waar hij ook niet mee kan leven: hij tracht de situatie meester te worden, die hij in oorspronklike vorm niet heeft aangekund, door deze herhaaldelijk uit vrije wil (?) nog eens onder ogen te zien (Erikson, 1967:206). Miller zegt van die herhalingsdwang, dat in die dwang de mens twee zaken in zichzelf lijkt te ontdekken, en wel "de functie van de eigen ouder" en de "eigen verdrongen geschiedenis van zijn kindentijd". 
meisjes te benaderen van onomkeerbare invloed te zijn op hun gender-identiteit. De gegevens voor deze gedachte komen uit onderzoeken naar gender-identiteit en genderrolgedrag bij pseudo-hermafroditisme (Hampson \& Hampson, 1961:1410-1413; Landman, 1969:149). Bij de mannelijke hermafrodiet ontwikkelt de gonade zich tot testis, maar de geslachtsbuizen en de secundaire geslachtskenmerken lijken sterk op die van de vrouw. Het komt veel voor dat het geslacht van deze personen verkeerd wordt vastgesteld bij de geboorte, een vergissing die dan pas in de puberteit of in het huwelijk duidelijk wordt. Het is nu het verkeerd vastgestelde geslacht ${ }^{19}$ van de baby die de ouders en de verdere sociale omgeving tot een sterke geslachtsgebonden benadering van hun kinderen brengt. Wat uit studies over het consistente sex-typingsgedrag van ouders met betrekking tot hun pseudo-hermafrodiete kinderen ${ }^{20}$ blijkt, is dat opgelegde geslachtswijzigingen, na het ontdekken van het echte biologische geslacht van hun kind na het tweede of derde levensjaar vrijwel onmogelijk is en volgens genoemde onderzoekers af te raden is. De gender-identiteit blijkt vrijwel geheel bepaald door het geslacht waarin het kind door de ouders en anderen was opgevoed en tegemoet getreden ${ }^{21}$. Zelfs de genetische informatie (terug te vinden in de geslachtschromatine ${ }^{22}$ ) bleek van ondergeschikt belang.

\footnotetext{
${ }^{19}$ Landman (1969:149) wijst er op, dat men vroeger meende dat het geslacht van de mens alleen maar vast te stellen was door een inwendig onderzoek van het buizensysteem en de geslachtsklier. Tegenwoordig kan met een onderzoek van het 'geslachtschromatine' worden volstaan.

${ }^{20}$ Dus kinderen met het zogenaamd adrenogenitaal syndroom.

${ }^{21}$ Ook Mead (1965:284) demonstreert haar vondst dat het anatomisch bewijs van het geslacht tegenover de maatschappelijke conditionering weinig gewicht in de schaal lijkt te leggen. $\mathrm{Ze}$ schrijft over een 12-jarige jongen, die altijd als meisje had geleefd, Maggie genoemd werd, meisjeskleren droeg en niet op de gedachte kwam, ondanks de wetenschap van de fysieke bewijzen aan zijn lichaam, zich als een jongen te gaan manifesteren. Mead concludeert "dit bizarre geval bewijst de kracht van de maatschappelijke classificatie in vergelijking met die van het louter anatomische lidmaatschap van een sekse. Het is deze maatschappelijke classificatie die het de maatschappij mogelijk maakt om in de geest van kinderen twijfel en verwarring aangaande hun sexuele positie te zaaien".
}

${ }^{22}$ Uit onderzockingen van Barr en Carr (1962), Bertram en Moore (1978) aangehaald door Landman, bleck dat in $\mathbf{4 0}$ tol $80 \%$ van alle cellen van normale vrouwen men vrijwel altijd tegen de kernmembraam aan, een klein donkerkleurig lichaampje aantrof, dat zelden - indien ooit - in normale cellen van de man gezien werd. Hoewel de aard van het chromatinelichaampje aanvankelijk niet bekend was, werd spoedig duidelijk dat het een van de twee $\mathrm{X}$-chromosomen van de vrouwelike cel is. Dat lichaampje wordt nu het geslachtschromatinelichaampje genoemd. Vrouwelijke cellen zijn dus chromatine-positief en de mannelijke chromatien-negatief (Landman, 1969:79). 


\subsubsection{Stimulerende culturele factoren?}

Net als bij het fenomeen homosexualiteit kan men hier en daar de opvatting vernemen, dat transsexualiteit een verschijnsel is, dat op de golven van een permissieve westerse cultuur haar kansen kan krijgen en daarom meer lijkt voor te komen dan vroeger. Het is de vraag of dat waar is? Steeds in de geschiedenis waren er meisjes loos, die gingen varen als lichtmatroos, waren er mannen die het klooster ingingen als non (pas bij ziekten en dood werd dit dan ontdekt). Ook zijn er beschrijvingen van Indianenstammen bekend, bijvoorbeeld het volk van de Tsjamboeli-Indianen, waar er jongens zijn, die als berdache bekend zijn (Mead, 1965:284). Gooren vermeldt dan ook nog het voorkomen van de gender-dysforie in Jemen (xanith) en in India (hijera) en de door hem zelf waargenomen gevallen in Birma (de atsjauw). Gooren verbindt aan het niet alleen in het westen voorkomen van mensen met gender-dysforie de conclusie "dat transsexualiteit geen uitvloeisel is van de permissieve zedelijkheid van het westen" (Gooren, 1986:19).

\section{TRANSSEXUALITEIT EN MEDISCHE ETHIEK}

In het ethisch denken binnen de gezondheidszorg is de transsexualiteit pas laat in de aandacht gekomen (Van Emde Boas, 1974:475-478). Sporken geeft min of meer een argument voor die late aandacht, als hij schrijft dat de vele onduidelijkheden rondom het gender-dysforebeeld het uitermate moeilijk maken om vanuit ethisch standpunt tot een duidelijke opvatting te komen (Sporken, 1977:195). Of dat een goede verklaring is is niet duidelijk, wel, dat in het morele beraad van de Koninklijke Nederlandse Maatschappij ter Bevordering van de Geneeskunst de morele stellingname ten aanzien van de vraag om detranssexualisatie steeds werd ingegeven door het verschuivende inzicht in de ethologie van de gender-dysforie. In Nederland werd in 1959 de eerste detranssexualiserende operatieve ingreep verricht. De verontwaardiging in Nederland daarover was zo groot, dat de overheid een commissie instelde om haar te adviseren over het nut van een dergelijk medisch handelen. Deze commissie adviseerde vijf jaar later negatief. In 1960 reeds nam de KNMG, op grond van de gedachte dat transsexualiteit een psychische afwijking was, te weten een waan, een negatief standpunt in. Het is ethisch interessant dat de maatschappij met een beroep op een zogenaamd naturalistic argument - om Moore (1978) te citeren - de geslachtsveranderende operaties afwijst. Ze stelde namelijk dat

* een dergelijke operatie geen therapie kan vormen voor een psychische afwijking de enige weg zou psychotherapie en medicamenteuze behandeling zijn en 
* dat men eerbied dient te hebben voor de natuurlijke gegevenheid van het geslacht waartoe men behoort (Sporken, 1977:195/275).

In 1965 wil de KNMG inzien, zij het aarzelend, dat er bij sommige transsexuelen wel reële therapeutische verwachtingen gekoesterd mogen worden en geeft naast de herhaalde afwijzing van 1960 toch enige ruimte voor transformatief operatief handelen. Dit toelaten van enige speelruimte leidde er toe, dat in 1967 al de KNMG haar aanvankelijke afwijzen moest relativeren. In 1977 adviseerde de Nederlandse Gezondheidsraad, op grond van hernieuwde inzichten aan de overheid, dat bedoelde somatische aanpassingen therapeutisch effectief kunnen zijn en achtte derhalve deze aanpassingen moreel verdedigbaar.

Met de oprichting van de Stichting Nederlands Gender Centrum (1972) emancipeert de transsexualiteit en krijgt men in medische kringen meer oog voor de authenticiteit van de existentiële nood van de gender-dysfore mens.

In de officiële medische ethiek is het probleem van de morele toelaatbaarheid van de endocriene en transformatieve chirurgische ingrepen nog nauwelijks besproken. Sporken bespreekt genoemde morele vraag wel. Voor hem is de morele kernvraag of een zo diep ingrijpende behandeling de persoon in diens totaliteit ten goede komen kan? De behandeling moet de zelfontplooiing als man of vrouw bevorderen, anders heeft medisch handelen geen zin. Hij schrijft anno 1977 "persoonlijk ben ik van mening dat het bewijs hiervoor nog niet afdoende geleverd is, ofschoon ik mij realiseer dat het tegendeel evenmin met zekerheid bewezen is. Deze onzekerheid en de daaruit voortvloeiende risico's noodzaken m.i. tot grote terughoudendheid". Het onderzoek van Kuiper - anno 1985 - naar het effect van de geslachtsaanpassende behandeling bij 143 transseksuelen, leverde het resultaat op dat geen van de 143 onderzochten aangaf nog gevoelens van gender-dysforie te ervaren. Het merendeel van de onderzochten gaf aan vertrouwen te hebben in de nieuwe gender-rol en tevreden te zijn met de integratie van deze rol in de dagelijkse leefwerkelijkheid, is tevreden met het eigen lichaam en oordeelt positief over het eigen leven. Met deze gegevens kan de twijfel van Sporken opgeheven worden. Tegenover deze optimistische resultaten van de transformatieve behandeling staan wel schaduwzijden, zoals verlies van de oude sociale omgeving, verplichte echtscheiding, oude banen, het moeten verhuizen, enzovoort. Maar deze problemen hangen dan niet meer samen met het onbehagen van de aanvankelijke gender-dysforie.

Het Handboek gezondheidsethiek noemt transsexualiteit twee keer maar dan in het kader van het gezondheidsrecht (De Beaufort \& Dupius, 1988:83) en de vraag of een 
15-jarig kind het recht heeft buiten zijn ouders om de lange weg van de detranssexualisatie te gaan (De Beaufort \& Dupius, 1988:322). Tot een ethische discussie van de vraag zelf komt het in dit handboek niet, wat mij een omissie lijkt.

Verder heeft Douma in het Nederlands Dagblad een artikel over transsexualiteit geschreven (1988a:3) waarin hij positief lijkt te adviseren waar het de vraag om detranssexualiserende operaties betreft. Douma (1988b:7) schrijft als conclusie van zijn overwegingen (onder anderen over het scheppingsgegeven, dat God de mens schiep en wel "als man en vrouw"),

\begin{abstract}
... op grond van welke bijbelgegevens kan ik (...) een afwijzing van geslachtsveranderende operaties funderen? Als ze er zijn, zal ik het doen; maar ik ken ze niet. Ik weet dat er veel nood is die niet kan worden afgeschud, bijvoorbeeld die van de homofiel die op andere manier geholpen moet worden dan met homoseksuele contacten. Maar moet een transseksueel met zijn moeiten blijven leven, als er verlichting door geslachtsverandering mogelijk is? Ik durf dat niet voor mijn rekening te nemen.
\end{abstract}

Op grond van verschillende reacties op zijn artikel herneemt Douma zijn artikel, maar niet - zo lijkt mij - zijn standpunt. Douma heeft uit de vele reacties blijkbaar vooral geleerd dat hij het verschijnsel transsexualiteit op te smalle basis bestudeerd heeft en herneemt zijn artikel dan om eerst verder te studeren en intussen misverstanden te voorkomen.

\title{
3. ANTROPOLOGISCHE UITGANGSPUNTEN VOOR EEN MORELE EVALUATIE VAN DE VRAAG OM DETRANSSEXUALISATIE
}

Wat kan de ethicus, die werkt met een analyse van de gestalten der liefde als uitgangspunt binnen de medische relatie tussen arts en patiënt, zeggen als het gaat om de vraag van de toelaatbaarheid van endocriene en transformatieve chirurgische handelingen op een gezond mensenlichaam? Of is deze vraag al verkeerd? Gaat deze vraag al niet uit van een beschouwing over de mens, die in zich het morele dilemma creëert, namelijk van een dualistische visie op de mens? Een dualistische visie die stelt dat het lichaam niet een specifieke eigenheid is, maar een drager van ziel, geest, psyche, maar ook van het aan het lichamelijk substraat gebonden geslachtelijke, namelijk het mannelijk of vrouwelijk zijn. Juist een ethische analyse van de niet-originaire liefdesverhoudingen binnen de gezondheidszorg kan niet om een beschouwing van de mens, die hier als transsexuele medemens voor ons verschijnt, heen. Ik citeerde reeds met instemming Fromm's uitspraak dat over liefde spreken over de mens spreken is ${ }^{23}$.

\footnotetext{
${ }^{23} \mathrm{Als}$ een doorlopende illustratie van deze gedachte verwijs ik naar het boeiende en diep gravende werk van De Knijff (1987)
} 
Wat ons het fenomeen van de transsexualiteit (maar ook die van het pseudo-hermafroditisme) lijkt te leren, is het feit dat de tot nu toe gangbare dualistische en psychofysische eenheid verkondigende mensbeschouwingen stuk lopen (Van Emde Boas, 1974:477) - stuk lopen omdat blijkbaar het lichamelijk substraat niet per definitie de drager van de mannelijke of vrouwelijk identiteit lijkt te zijn ${ }^{24}$.

Het beeld van de transsexualiteit wekt vragen op als: Man en vrouw schiep Hij hen, maar, wat betekent dat als genetisch man en vrouw niet in alle gevallen ook psychisch man- en vrouw-zijn impliceert? Hoort het tot de constitutieve betekenis voor het beelddrager-Gods zijn van de mens dat zij als man en vrouw dat beeld dragen? Gaat het in dat beeld dan om de uitspraak dat een mens genetisch én psychisch als man of als vrouw ter wereld komt, of gaat het hier om een zogenaamd analogia relationis? (Barth, 1957:72) in die zin, dat de mens pas echt mens is (wordt?) in een man-vrouw verhouding? Wat ook precies het antwoord moge zijn, duidelijk is, dat dit antwoord niet kan slaan op de gender-dysfore mens, want die voelt zich op egosyntone wijze of man of vrouw, dwars tegen de biologische blijken van het tegendeel in en vaak ook los van alle schuldgevoel daarover ${ }^{25}$. De vraag moet dan ook anders worden gesteld: kan een mens los van zijn geslachtelijkheid ook voldoen aan het beeld Gods, of - nog anders - kan de transsexuele mens ook tot zijn/haar bestemming komen?

Om nog even op het boven genoemde dualistisch mensbeeld terug te komen. Ook op dit punt roept de transsexueel vragen op, bijvoorbeeld: wat aan te vangen met het oude dualistische mensbeeld - wat gelijk ook het gangbare medisch denkmodel is - en haar schijnbare opponent, dat de mens als psycho-fysische eenheid wil verstaan?

Daar waar het klassiek dualistische denkschema over de mens gehanteerd blijft zal men - in de meeste gevallen - elke transformatieve ingreep in een gezond en normaal menselijk lichaam als een ernstige verminking ervaren en op grond daarvan tegen die chirurgische handelingen zijn 26 . Het dualistisch medisch denken lijkt zich op het

${ }^{24} \mathrm{Het}$ is hier vermeldenswaard, dat 2 pro mille van de wereldbevolking aan intersexuele defecten lijdt - met name waar het gaat om de somatische tussenvormen (Overzier, 1961:2).

${ }^{25}$ N.B. Ik suggereer niet, dat schuldgevoel hier een noodzaak is, maar constateer hier slechts feitelijk.

${ }^{26}$ Van Emde Boas (1974:476) vermeldt dat ook politie functionarissen, die toendertijd het dreigement hebben geuit dat chirurgen betrokken bij detranssexualiseringsingrepen "met de justitie in aanraking zouden kunnen komen, wegens het opzettelijk tocbrengen van zwaar lichamclijk letsel" eigenlijk net zo dualistisch dachten als de artsen meestal doen. 
biologisch lichaam te richten met voorbijgaan aan het psychische leed en de grote zielestrijd van de gender-dysfore mens"27. We zagen dit ook terug in het 1960standpunt van de KNMG ten opzichte van transsexualiteit.

Ook het afwijzen van het dualistische denken, zoals dat bijvoorbeeld in de benadrukking van de 'eenheid van lichaam en ziel' blijft gebonden aan het klassieke dualisme. Dooyeweerd schreef eens, dat het proclameren van de mens tot "eenheid van ziel en lichaam " niets zegt, want "ook zulk een conceptie blijft abstract en slechts van negatieve strekking: ze spreekt slechts de afwijzing van het dualisme uit, zonder in positieve zin iets bij te dragen tot een wezenlijk inzicht in de eenheid der menselijke natuur" (Dooyeweerd, 1942:753). In de grond van de zaak verduisteren zij, die de eenheid van lichaam en ziel proclameren het eigenlijke probleem, namelijk dat van de echte eenheid van de mens. Dooyeweerd schrijft: "Wie de mens als 'eenheid van lichaam en ziel' meent te kunnen verstaan, begint toch weer met aanvaarding van een dualiteit, die men dan weer in een hogere eenheid zou moeten verzoenen" (Dooyeweerd, 1942:768).

Een goed voorbeeld van het gebonden blijven aan het dualisme - en dat tegen wil en dank - vormt Max Scheler's poging de eenheid van de mens te beschrijven. Scheler makkt eerst een onderscheid tussen lichaam en geest, maar poneert gelijkertijd hun onderlinge samenhang en wisselwerking (Scheler, 1966:40). Scheler stelt eerst dat de geest van alle fysiologische omstandigheden onafhankelijk is (Scheler, 1966:40). De menselijke geest is in staat zijn niet alleen de hem omringende werkelijkheid, maar ook om zijn eigen fysiologische en psychische toestanden "gegenständlich" te maken (Scheler, 1966:42). De geest zelf is "gegenstandunfähig", is zuivere actualiteit. De geest "hat sein Sein nur im freien Vollzug seiner Akten" (Scheler, 1966:48). Heel het menselijk (ook het lichamelijk) functioneren wordt door de geest van de mens in regie genomen. Dat doet de geest middels zijn vermogen of act der Ideierung (Scheler, 1966:49). De act der Ideierung is volgens Scheler een geesteswerkzaamheid die verschilt van alle technische intelligentie, die ook bij dieren (in zekere mate) aanwezig is.

\footnotetext{
${ }^{27}$ Brockman (1986:152) schrijft: "... hetzelfde medische model dat de scheiding tussen innerlijkheid en uitcrlijkhcid in stand houdt en tot absolute voorwaarde voor het eigen handelen neemt, moet door toepassing van zijn op die grondslag ontwikkelde techniek deze scheiding overschrijden en relativeren! Het is om deze reden, en niet om een of andere communicatietheorctische bijzonderheid, dat ook in het medisch-psychiatrische sfeer de toegang tot de transsexucle persoonlijkheid moeilijk is en blijft.
} 
Scheler erkent dus enerzijds de mogelijkheid van de mens om zijn concrete psychischvitale-fysische werkelijkheid te kunnen transcenderen, maar anderzijds, zo stelt hij, kan de geest ook weer niet zonder een natuurlijk substraat. Dat laatste blijkt als Scheler de vraag beantwoordt waar de geest de energie vandaan haalt om te 'ideieren'? In de lijn van Freud, maar met een variatie op hem, zegt Scheler, dat de geest van zichzelf uit geen energie heeft. De energie die de geest nodig heeft, haalt hij uit het afwijzen van de door de driften beheerste werkelijkheid (Scheler, 1966:56-66), iets waarmee Scheler eigenlijk aangeeft theoretisch geen raad te weten met de eenheid van de mens en deze eenheid dan toch weer zoekt in én van de polen van de dualiteit lichaam en geest. Binnen het denken van hen die de eenheid van lichaam en ziel proclameren, kan het fenomeen van de transsexualiteit ook geen plaats krijgen, want die geproclameerde eenheid is hier wel heel duidelijk verbroken en ook in de gestelde eenheid van lichaam en ziel blijft het lichaam een neutrale drager van een 'iets', dat Scheler dan Geist noemt. De transsexualiteit roept vermoedens van een gebroken, of gestoorde relatie tussen lichaam en geest op. Om in de lijn van Scheler te blijven: je zou kunnen stellen, dat de transsexueel een 'geest' bezit dat inderdaad vrij is van alle fysiologische gebondenheid, maar wil deze transsexuele geest kunnen bestaan, dan zullen er in haar genese toch allerlei blijken van afwijzingen van de door de driften beheerste werkelijkheid, van een "triebhemmenden Wollens" aanwijsbaar moeten zijn (Scheler, 1966:57). Psychiatrisch onderzoek lijkt geen steun te bieden voor een dergelijke ethologische systematiek achter de gender-dysforie. Van Embde Boas kon in haar artikel van 1974 slechts vier gevallen van (vermeende) transsexualiteit melden, die bleken terug te gaan op de afwijzing van latente homosexuele wensen. Ook in latere onderzoekingen van Kuiper (1986:129) naar (o.a.) de sexuele voorkeuren van transsexuelen, blijkt dat van de VM transsexuelen $8,6 \%$ homo/lesbische en van de $M V$ transsexuelen $19,2 \%$ homo/lesbische voorkeuren hadden. Dit gegeven maakt de oorsprong van de gender-dysfore geest nog alleen maar problematischer.

Het is - mijns inziens - voor alles de vraag of al die hooggestemde antropologische beschouwingen over 'het wezen van de mens', de 'menselijke eenheid' of Schelers Geist niet iets anders op het oog hebben dan de door het transsexualiteitsbeeld aangetaste relatie van lichaam en ziel.

Ik denk dat in Dooyeweerds kritiek op zowel het dualisme als op de in de netten van het dualisme gevangen pscho-fysische eenheidsdenken een antwoord ligt op de door mij gestelde vraag. Na zijn opmerking, dat zij die de eenheid van lichaam en ziel voorstaan toch weer een "hogere eenheid" moeten zoeken om het impliciete dualisme te verzoenen, stelt Dooyeweerd (1942:769) namelijk de vraag: "Maar waar is dan die 
hogere eenheid zelf te vinden? Zij mag dan ndch in het 'lichaam', noch in de 'ziel' worden gezocht?" Dooyeweerds antwoord is:

De mens is niet de "eenheid van ziel en lichaam", maar 's mensen lichaam als zijn gehele tijdelijke bestaansvorm komt ecrst tot innerlijke eenheid in zijn religieuze wortel, in de ziel of geest des mensen. (...) In de ziel is het totale menselijke bestaan als geestelijke cenheid samengevat. (...) De ziel is de mens zelf in zijn innerlijke totaliteit, die zich in het lichaam differentieert binnen de tijdshorizon, en zij kan dit alleen zijn, omdat zij een geestelijke eenheid boven alle tijdelijke verscheidenheid is, waardoor zij ook ons begrip te boven gaat (Dooyeweerd, 1942:769).

\section{Of, zoals Dooyeweerd elders (1969:89) zegt:}

The human body is man himself in the structural whole of his temporal appearance. And the human soul, in its pregnant religious sense, is man himself in the radical unity of his spiritual existence, which transcends all temporal structures.

In mijn woorden gezegd: de aard van de eenheid van de mens is theoretisch ongrijpbaar, is wellicht een regulatief idee dat het menselijk denken steeds verder voert in de poging om de werkelijkheid, ook de mens zelf, in begripsmatige samenhang en énnheid te vatten. Als idee van eenheid voert ze het denken tot haar grenzen en moeten we, met de erkenning van die grenzen, zwijgen en inzien dat het hier om een eenheid van het menselijk bestaan - de geest, het ik of het hart - gaat, dat de grenzen van ons tijdelijk bevatten en bestaan te boven gaat. Maar, wat we in geloof wel weten en wijsgerig mogen uitspreken is ons besef, dat deze eenheid te maken heeft met het tot zijn of haar bestemming komen van de mens. Of die mens nu gender-dysfore is of niet, dat kan aan die bestemming niets toe of af doen.

De problematiek van de transsexueel ligt, zo zagen we, in de incongruentie tussen lichaam en ik-besef. Het ik-besef van de transsexueel geeft hem/haar het gevoel niet dat te zijn wat de uiterlijkheid van het lichaam hem/haar zegt te zijn. Het is volgens Dooyeweerd toch precies het menselijke $i k$ dat als religieus centrum van het menselijk bestaan de eenheid van de mens uitmaakt. Van dit ik of zelfbewustzijn zegt Dooyeweerd dan:

Het zelfbcwustzijn draagt noodzakelijk tegelijk een den tijd transcenderend en den tijd immancnt karakter. De diepere identiteit, welke in de zelf-heid beleefd wordt, is een transfunctionelc, het is het zich een-en-dezelfde weten in en boven alle kosmisch-tijdelijke zinfuncties en het zich zijn tijdelijke zinfuncties als eigen weten (Dooyeweerd, 1931:97).

Ook hier is er, mijns inziens, geen sprake van een belemmering dat de mens - in religieuze zin - zijn bestemming mist, als hij/zij een gender-dysfore zich-een-en-dezelfde weten bezit. 
Met de gegeven antropologische beschouwing over de menselijke eenheid en diens bestemming heb ik de weg vrij gemaakt voor een ethische beschouwing over de vraag of de geneeskundige de transsexueel moet volgen in het primaat van zijn eigen overtuiging, dwars tegen de biologische werkelijkheid in?

\section{DETRANSSEXUALISATIE: VRUCHT DER LIEFDE}

Uitgangspunt van de ethische bezinning op de vraag naar de detranssexualisatie is ten eerste de boven gegeven korte schets van antropologische overwegingen. Verder de vraag wat wel precies de aard van het medisch handelen is en hoe zich daarin de morele liefde toont?

Lindeboom (1965) heeft in zijn Opstellen over medische ethiek de medische grondsituatie als volgt omschreven:

De medische grondsituatie is overal daar, waar een zieke een arts om hulp vraagt. De zieke is cen mens, die door zijn lichamelijke of geestelijke gesteldheid in nood verkeert. Hij vraagt in die nood hulp van iemand, van wie hij mag veronderstellen, dat hij die geven kan en wil. Dit is het oerfenomeen, waaruit zich de hele geneeskunst heeft ontwikkeld.

Lindeboom merkt dan, als waarschuwing op dat men "... dit eigen en oorspronkelijke karakter van de medische situatie, waarin een mens in vertrouwen en een mens met weten 28 en geweten zich te samen vinden om een nood te lenigen". Dit moet men in het oog houden, "hoe dikwijls ook de situatie zich in onduidelijke, gewijzigde, verbasterde of verminkte vorm voordoet in de verwikkeldheid van het moderne leven" (Lindeboom, 1956:27). Strijbos(1988), Lindeboom besprekende, vat samen: het gaat Lindeboom hier duidelijk om de normatieve structuur van de geneeskunde en daarin zijn drie kernmomenten te onderscheiden:

* De zieke is een mens in nood.

* De zieke vraagt een arts om hulp.

* De zieke mens is een mens in vertrouwen.

Popma $(1977: 9,10)$ merkt over de grondsituatie van de gezondheidszorg op dat het daarin gaat om een ik-ben-ziek-situatie en een ik ben dat als totale persoon. Bij de

\footnotetext{
${ }^{28} \mathrm{Het}$ behoort tot de normatieve structuur van de medische situatie dat de arts ook echt weet, dat wil zeggen medisch-technisch kundig is, maar die typisch medische verantwoordelijkheid dient doortrokken te zijn met de liefde in zijn binnen de medische situatie typische uitwerking van curing en caring.
} 
transsexueel uit zich dat ziek (?) zijn in de incongruentie-gevoelens tussen zijn van het lichaam afwijkende egosyntone gender-identiteit. Maar ziek in klassieke zin lijkt de transsexueel niet: noch lichamelijk, noch psychiatrisch is er aan hem/haar iets op te merken. De nood van de transsexueel zit in de als pijnlijk ervaren discrepantie tussen uiterlijkheid en innerlijkheid en van die pijnlijke discrepantie wil hij/zij af. Wat doen we met die vraag? Is het eigenlijk wel alleen de vraag van de transsexueel zelf, is het ook niet de problematiek van de gender-normale (?) mens die niet wil zien, dat iedereen leeft in een - om Popma te citeren - gestoorde wereld, die sinds de zondeval niet meer ongestoord aan zijn bestemming voldoet en zijn oorspronkelijke integriteit kwijt geraakt is. Maar ik doe nu een religieuze uitspraak en wil me daarmee verzetten tegen alle beweringen van christelijke zijde, dat het leven zoals dat zich in zijn zogenaamd 'normale' variaties toont, zó door God gegeven is en derhalve in alle niet pathologische omstandigheden in tact gelaten moet worden ${ }^{29}$.

Ethisch gesproken zou de discussie over eerbied voor het leven en/of de kwaliteit van het leven, zoals deze rondom vragen als abortus en nog meer rond die van de euthanasie worden gevoerd, moeten worden geïntroduceerd in de afweging van de vraag: wel of geen detranssexualiserende ingrijpen van de medische wereld. In christelijke kring wordt vaak verwezen naar het principe van de eerbied voor het leven dat door God gegeven is. Omdat God het leven geeft, heeft de mens niet het morele recht vrijelijk te beschikken over die leen-gave. Binnen de ethische discussies lijkt dan het genoemde principe de kern van de christelijke ethiek te zijn. Toch is dat maar de vraag. In de studie van Musschenga (1987) over het principe van de kwaliteit van leven als criterium voor medisch handelen wordt genoegzaam duidelijk gemaakt, dat principes als heiligheid van het leven, eerbied voor het leven en het principe eerbied voor alles wat leef (door A. Schweitzer zo verwoord) afkomstig is uit "seculiere, vitalistische filosofieën en niet uit de christelijke traditie" (Musschenga, 1987:72). Het principe van eerbied voor het leven is, zo lijkt het, bijna altijd in biologische zin geïnterpreteerd. In die biologische interpretatie moet dit principe voeren tot standpunten, waarin het leven in zijn uiterlijke, waarneembare vormen onaangeraakt moet blijven, ondanks de erkenning van alle nood dat door mensen in het biologische lijf levende geleden wordt. Van der Meer (1987:118) schrijft over de toekomst van de medische ethiek het volgende:

Sinds een aantal jaren beschouwt men in de medische ethiek niet meer het leven als zodanig als een groot en waardevol goed, maar het leven in zijn emotionele, sociale en psychische

\footnotetext{
${ }^{29}$ In die zin lijken de debatten over abortus, sterilisatie, genetische manipulatie en detranssexualistie op elkaar. Want, wat deze 'medische' handelingen doen, is ingrijpen in het niet zieke lichaam.
} 
dimensies. Met andere woorden: niet het leven in zijn biologische zin, maar de kwaliteit van dit leven is het belangrijkste in onze ethische overwegingen om tot bepaalde beslissingen te komen, 30

Ik denk, dat het christelijk is om in gevallen waar aan de arts de vraag gesteld wordt om detranssexualisatie, niet alleen de principes van de eerbied of de heiligheid van het leven moeten gelden, maar dat de vraag wat de kwaliteit van het menselijk leven is het uitgangspunt moet zijn, met nadruk op menselijk. Niets in mijn antropologische grondschets verzet zich tegen de gedachte dat ook de transsexuele mens een beelddrager(ster)-Gods kan zijn en met zijn/haar leven dienstbaar kan zijn aan God door bepaalde waarden in dit leven te realiseren.

Met de verwijzing naar de menselijke mogelijkheid waarden te realiseren in dienst aan God en de medemens, raak ik een ander punt van de nood van de transsexueel, namelijk het voor hem/haar noodlottige feit, dat het lichaam niet zo maar een materieel substraat van mijn ik-heid of geest is, maar - binnen de tijdelijke werkelijkheid - ook een brandpunt van waarden, normen en verwachtingen. De transsexueel brengt met zijn/haar vraag de gevestigde orde van onze culturele waarden en normen aan het wankelen. Het is niet alleen zijn/haar probleem maar zeker ook dat van de zogenaamd gezonde mensen (Broekman, 1986:150). Daarom: het lijden aan en het problemen hebben met zijn/haar uiterlijkheid, is deel van de maatschappelijke orde en toon zich niet alleen bij de gender-dysfore mens. Ook bij hen die om niet medische redenen vermageren, met de mode meegaan, zich uiterlijk verfraaien en in de maten die mannequins of schoonheidskoninginnen moeten hebben.

Samenhangend met het zo juist gezegde is er dan nog een andere aantasting die uitgaat van het beeld van de transsexualiteit (eigenlijk ook van alle intersexualiteit op de wereld). Want, dat beeld tast ons zelfvertrouwen in onze gender-identiteit en de daarin belichaamde waardenbeleving en waardenverwerkelijking aan. Kortom: op allerlei wijzen blijkt de problematiek van de verschijningsvorm van de transsexualiteit niet louter die van de individuele transsexueel te zijn, het is ons aller probleem. En vanuit de visie dat heel het menselijk bestaan en heel de menselijke lichamelijkheid een geschondenheid vertoont, draagt de transsexueel zijn/haar speciale lot en niettranssexuelen weer een ander. Op dit vlak wordt ieder afzonderlijk en uniek lijden gerelativeert en blijken alle mensen gelijk te zijn. Of de ene mens meer moet lijden dan de ander is niet alleen een metafysische of retorische vraag, maar ook een, voorzoverre dat in de (medische) macht van de mens ligt, van liefde en gerechtigheid.

\footnotetext{
${ }^{30}$ Op bladzyde 120 schrijft Van der Meer zells, dat Schweitzers "eerbied voor het leven" niet meer kan gelden. Een betere formulering is: "Liefde voor de zieke medemens in alle aspecten van zijn leven". Ik stem daarmee in.
} 
Ik sluit af met de opmerking, dat daar waar de liefde aangeduid kan worden met een onbaatzuchtige gerichtheid op de persoon van de ander met de intentie die ander in zijn/haar persoon-zijn niet aan te tasten, de persoon tot zijn of haar recht te laten komen door steeds de ander sub speci boni te zien en het geheimenis van de ander niet te willen schenden in zijn persoon 'thuis te willen laten zijn' moeten we dan niet zeggen dat onder zorgvuldige afweging, diepgaande toetsing van het lijden van de genderdysfore mens, en als we naar eer, weten en geweten proberen te voorkomen dat de enkele lijdende aan de zogenaamd Geslechtsverwandlungswahn toch de screening doorkomt, dat het dan verantwoord is te zeggen dat de medicus precies aan de normativiteit van de medische professie voldoet als hij zegt dat de transsexueel moet kunnen ervaren dat hij/zij niet alleen gelaten wordt met zijn/haar probleem, "... hij moet mogen rekenen op solidariteit vanuit de medische professie" (Gooren, 1987:23). Omgekeerd moet de transsexueel zich realiseren dat de medicus ook mens is en als mens niet klaar hoeft te zijn met de geweldige aanvechtingen die zijn/haar probleem op de niet-transsexuele wereld uit doet gaan. Zo blijven wij mensen in al onze vormen van lijden elkaar in liefde trouw.

\section{BIBLIOGRAFIE}

BARR, M.L. \& CARR, D.H. 1962. Correlations between sex chromatin and sex chromosomes. Acto Cytol, 6:34.

BARTH, K. 1957. Kirkliche Dogmatik III, 1. Zürich : EUZ-Verlag

BANDURA, A. ROSS \& ROSS. 1969. Social learning theory and identification processes. (In Goslen, D.A. red. Handbook of socialization theory and research. Chigaco : Rand McNally.)

BENJAMIN, H. 1966. The transsexual phenomenon. New York: Julian Press.

BOWLBY, J. 1971. Maternal care and mental health. Genève : W.H.O.

BROEKMAN, J.M. 1986. Transseksualiteit: het uiterlijk als norm en waarde. (In Gooren , L.J.G. red. Transseksualiteit. Alphen aan de Rhijn/Brussel : Samson Stafleu. p. 148-157.)

COHEN-KETTENIS, P. 1986. Het verschijnsel transseksualiteit. (In Gooren, L.J.G. red. Alphen aan de Rhijn/Brussel : Samson Stafleu. p. 13-24.)

DE KNIJFF, H.W. 1987. Venus aan de leiband. Europa's erotische cultuur en christelijke sexuele ethiek. Kampen : Kok.

DOOYEWEERD, H. 1931. De crisis der bumanistische Staatsleer in het licht eener Calvinistische kosmologie en kennistheorie. Amsterdam : Ten Have.

DOOYEWEERD, H. 1942. De mens: Inleiding tot de athropologie van de Wijsbegeerte der Wetsidee. (Typoscript dl. II, Dooyeweerd-archief). Amsterdam : V.U.

DOOYEWEERD, H. 1966. A new critique of theoretical thought. Toronto : The Presbiterian and Reformed Publishing Company.

DOUMA, J. 1988a. Van lichaam veranderen: interseksuelen en transseksuelen. Nederlands Dagblad: 3. Jan.1. 
DOUMA, J. 1988b. Reactie. Nederlands Dagblad: 7. Febr. 18. EICHER, W. 1985. Transsexualismus. Stuttgart : Gustav Fischer Verlag. ERIKSON, H. 1967. Het kind en de samenleving. Utrecht/Antwerpen : Het Spectrum FREUD, A. 1965. Das Ich und die Abwehrmechanismen. München : Kindler.

FREUD, S. 1967. Angst und Triebleben. In Gesammelte Werke. Band XV. Stuttgart : Fischer Verlag. FROMM, E. 1971. Liefhebben een kunst een kunde. Over de ontplooiing tot creatief mens-zijn. Utrecht : Bijleveld.

GOOREN, L.J.G. 1986. Biomedische aspecten van transseksualiteit (In Gooren, L.J.G. red. Transseksualiteit. Alphen aan de Rhijn/Brussel : Samson Stafleu. p. 50-56.)

GOOREN, L.J.G. 1987. Medisch handelen op bestelling. (In Thijs, L.G. red. Veranderende ethiek in do geneeskunde? Voordrachten ter gelegenheid van het afscheid van prof. dr. C. van der Meer als hoogleraar Inwendige Geneeskunde aan die Vrije Universiteit te Amsterdam. Amsterdam : V.U-Bockhandel. p. 11-23.)

GOOREN, L.J.G. 1990. HIJ en ZIJ. Inaugurele rede bij de aanvaarding van het ambt van bijzonder hoogleraar in de Transsexuologie aan de Vrije Universiteit te Amsterdam. Amsterdam.

GREEN, A.W. 1955. The middle-class male child and neurosis. (In Rose, A.M. ed. Mental health and mental disorder. p. 344-385.)

HAMPSON, J.L. \& Hampson. 1961. The ontogenesis of sexual behavior in men. (In Young, W.C. \& Corner, G.W. red. Sex and internal secretions. Baltimore: p. 1410-1430.)

HUYSE, F.J. 1986. Psychiater en transseksueel. (In Gooren, L.J.G. red. Transseksualiteit. Alphen aan de Rhijn/Brussel : Samson Stafleu. p. 57-73.)

KUIPER, A.J. 1986. De geslachtsaanpassende behandeling; enige resultaten. (In Gooren, L.J.G. red Transseksualiteit. Alphen aan de Rhijn/Brusscl : Samson Stafleu. p. 118-132.)

LAMB, M.E. 1974. A defense of the concept of attachment. Human Development, 17:376-385.

LANDMAN, J. 1969. Inleiding tot de embryologie. Utrecht : Academische Paperbacks.

LINDEBOOM, G.A. Opstellen over medische ethiek. Kampen : Kok.

MEAD, M. 1965. Seksualiteit en temperament. Utrecht/Antwerpen : Het Spectrum.

MILLER, A. 1981a. In den beginne was er opvoeding. Houten : Het Wereldvenster.

MILLER, A. 1981b. Het drama van het begaafde kind. Houten: Het Wereldvenster.

MONEY, J. \& ERHARDT, A.A. 1972. Man and woman, boy and girl: differentiation and dimorphism of gender identity from conception to maturity. Baltimore : John Hopkins University Press.

MOORE, G.E. 1978. Principia Ethica. Cambridge : Cambridge University Press.

MUSSCHENGA, A.W. 1987. Kwaliteit van leven, criterium voor medisch handelen? Baarn : Ambo.

OVERZIER, C. 1961. Die Intersexualität. Stuttgart: George Theme Verlag.

PERSON, E. \& OVERSEY, L. 1974. The transsexual syndrome in males I. Primary transsexualism. American Joumal of Psychotherapy, 28:4-20.

PINKHOF, H. 1963. Geneeskundig woordenboek. Haarlem : F. Bohn.

POPMA, K.J. 1977. Gestoorde wereld. Hilversum : Wytse Benedictus.

RICHTER, H-E. 1963. Eltern, Kind und Neurose. Die rolle des Kindes in der Familie. Stuttgart : Ernst Klett Verlag.

SCHELER, M. 1966. Die Stellung des Menschen im Kosmos. Bern/München : Francke Verlag.

SPORKEN, P. 1977. Ethiek en gezondheidszorg. Baarn : Ambo.

STRIJBOS, S. 1988. Het technische wereldbeeld. Een wijsgerig onderzoek van het systeemdenken. Amsterdam : Buijten \& Schipperheijn.

TEN HAVE, W. \& KIMSMA, G. 1987. Geneeskunst tussen droom en drama. Voortplanting, ethick en vooruitgang. Kampen : Kok.

VALENKAMP, M. 1984. Licfde en haar morcle implicaties. Refomational Form, 1(2):19-36.

VAN DEN BOUT, A.A. 1988. Reactie op J. Douna. Nederlands Dagblad, Febr.

VAN DER MEER, C. 1987. Quo Vadis? over de toekomst van de medische ethiek. (In Thijs, L.G. red. Veranderende ethick in de geneeskunde? Amsterdam : V.U. - Boekhandel. 
VAN EMDE BOAS, C. 1974. De behandeling van transseksisten in Nederland van 1953-1973. Medisch Contact, 29:475-478.

VERSCHOOR, A.M. \& POORTINGA, J. 1986. Een biografische beschrijving van transseksuele cliënten in Nederland. (In Gooren, L.J.G. red. Transseksualiteit. Alphen aan de Rhijn/Brussel : Samson Stafleu. p. 25-38.)

VAN IJZENDOORN, M.H., TRAVECHIO, L.W.C., GOOSSENS, VERGEER, M.M. 1988. Opvoeden in geborgenheid, een kritische analyse van Bowlby's attachmenttheorie. Deventer : Van Loghum Slaterus. 
